\title{
Challenges ahead of codification of environmental crime indices as an international crime
}

\author{
M. Jambozorg ${ }^{1}$ - M. Pournouri ${ }^{2}$ - S. A. Poorhashemi ${ }^{1}$ - D. Hermidasbavand ${ }^{1}$
}

Received: 17 March 2015/Accepted: 25 May 2015/Published online: 10 June 2015

(C) Islamic Azad University (IAU) 2015

\begin{abstract}
Today, the environment and addressing various aspects of its conservation and protection, whether in the national aspect or in the international dimensions, are one of the important issues of each society. Although in the past decades the international community attempted to prevent environmental damage by ratifying international instruments and encouraging states to pass civil and criminal law in their national law, up to the present time none of them has solved any of the current problems. Therefore, the need for environmental criminalization at the international level is seriously felt. However, there are challenges which have made the process of environmental criminalization happen at a lower speed. The present study defines environmental crime and its different kinds and discusses the inefficiency of the present international instruments in prevention and reduction of environmental damage, and it finally identifies and introduces the challenges in the way of indices codification of environmental criminalization as an international crime and tries to explain reasons for the failure of the international community to introduce environmental crime as the fifth international crime.
\end{abstract}

Keywords Criminalization challenges - Environmental crime $\cdot$ International crime $\cdot$ International instruments

M. Jambozorg

mjambozorg@yahoo.com

1 Department of Environmental Law, Faculty of Environment and Energy, Science and Research Branch, Islamic Azad University, Tehran, Iran

2 Faculty of Law, Central Tehran Branch, Islamic Azad University, Tehran, Iran

\section{Introduction}

In the nineteenth century, criminal law had mainly a domestic and national character and was only formulated to be enforced within certain communities. At the end of the nineteenth century especially after World War I, this situation changed and numerous international treaties were ratified for the punishment of criminals who were considered a threat to the international community. This process of internationalization of criminal law has been accelerated in recent decades, which has been as a result of factors such as the rise in war crimes, crimes against humanity, greater attention to the need to respect human rights at the international level and the spread of international terrorism.

These issues forced the international community to think about the establishment of the ad hoc courts. The establishment of the International Military Tribunal in Nuremberg, the International Military Tribunal for the Far East in Tokyo after World War II in order to bring war criminals of Germany and Japan to trial and then the establishment of the International Criminal Tribunal for the former Yugoslavia in 1993, in order to bring war criminals of Serbia to trial for the massacre of the people of Bosnia and Herzegovina, were the first major steps in planning a modern and sustainable international court.

In the later years, many countries and international organizations concluded that there should be an International Criminal Court, a permanent and independent one, for fighting against crimes. In 1988, 120 countries out of 160 total countries attending the Rome Conference joined the Rome Statute, and finally by the Rome Statute's entry into force in 2002, International Criminal Court (ICC) began its work (Rome Statute 1998). 
The ICC currently has jurisdiction over the four crimes of genocide, crimes against humanity, war crimes and crimes of aggression.

In fact, history and historical events have led the international community to identify the need for criminalization of these crimes, to find a solution to deal with the commitment of such crimes and to make the international community consider signing a single international statute, named the Rome Statute, and to establish the ICC to fight against the said four crimes. Therefore, it was the international demand that led to codification of international law, and the international community somehow found international security and interests in codification of international law. Now the question is: Why, despite the fact that the environment and its protection are currently one of the most important global issues, the international community has thus far failed in codification and criminalization of environmental crimes and these are referred to the national law of the states (Gibbs et al. 2010)? Only international crimes listed in the Rome Statute (1998) are punishable under certain conditions in the subset of war crimes. However, international law today seeks codification of international crimes such as torture, corruption and terrorism. In this case, the question arises: Whether the environmental crimes and damage cannot be considered to the extent of the abovementioned crimes (Wattad 2009)? This question is important because environmental issues and consequent damages are among the problems of humanity, the important point is the fact that damage inflicted on the environment in peacetime is much greater than damage inflicted on the environment during war, and environmental crimes are mainly committed in peacetime as a means of gaining monetary and huge profits.

Although in the last decades the international community made efforts to prevent environmental damage, these instruments mainly addressed preventive rules and regulations, compensation for damage and civil liability of states.

The present study attempts to answer questions: Although the occurrence of environmental damage has been increasing each day and humans have always been affected by the consequences of such damage including climate change, increase of storms, rise in the sea level of the earth, environmental migration and the loss of species, why have they failed to promote international environmental criminalization up to the present time and only developed one single international instrument such as the Rome Statute? Are the present international instruments accountable to the environmental issues? And if not, what are the challenges for international environmental criminalization?

\section{Definition of environmental crime}

In the past years and centuries, humans have treated the environment in a way as if they own it and they have never considered environmental crime and pathology. Gradually, with the increase in the earth's population the environmental pollution also increased, and with societies' industrialization environmental damage also multiplied in such a way that scientists believe that the damage inflicted on the earth and its environment by humans in the past 100 years is not comparable to that of the entire human history.

In fact, particular attention has been given to the environment and the environmental damage in the past decades, and soft and hard laws have been developed about the environment. The starting point in environmental protection by the international community commences along with the Stockholm Conference (1972), and the 26 principles of this conference played a significant role in the development of international environmental law.

After that, the Rio Conference (1992) was held in Brazil with the title of Environment and Development. In this conference, two important legal instruments about climate change and biological diversity were prepared to be signed by the states. In this conference, the Agenda 21 with the principles on the conservation of the forests was approved by the states.

After the Rio Conference, many changes in environmental protection were made both at the regional level and international level. Ten years later, the Sustainable Development Conference was held in Johannesburg (Earth Summit 2002) which was concluded by the announcement of eight main goals including poverty eradication, universal primary education, gender equality, reducing of child mortality, empowering of women, improving of maternal health, combating AIDS, malaria and other diseases, ensuring environmental sustainability and developing a global partnership for development.

Furthermore, the Rio+20 Conference (2012) which was held in Brazil, emphasizing principles defined in the past conferences, paid special attention to the reduction of poverty.

Although the said conferences each took an important step in the formulation of international environmental law, none of them considered environmental criminalization at an international level. However, the role of these conferences and instruments in laying the groundwork for further consideration to the environmental protection and consequently the states' efforts for environmental criminalization in both domestic and international levels cannot be ignored, taking into consideration that one of the important things that has been done by the states in the last decades in 
their domestic law was the environmental criminalization for environmental protection and conservation (Gibbs et al. 2010). In this regard, the governments concluded that, for the protection of the environment, measures cannot be limited to legal and administrative measures and to deal with environmental damage they should find a more serious approach (Mclaughlin 2000).

Hence, the sates tried to ratify criminal law and rules to protect the environment relying on the provisions, regulations and public law and with the help of international instruments in their domestic law; it also left many reflections and criticisms especially with developed countries and partly prevented environmental damage particularly environmental pollution in these countries (Smith 1995). But generally these measures have not been effective for environmental crimes at the international level. In the recent years, various definitions of environmental crime have been provided within the terms of legal doctrine, including the four cases cited below:

(1) Environmental crime is an activity which always occurs with the intention to harm or with the potential to harm an ecological or a biological system, and its goal is mainly gaining profits (Clifford 1998).

(2) Environmental crime is an act or omission which is stated in the law, and therefore the offender should be prosecuted or subjected to criminal prohibitions. These crimes must have caused serious damage and risk to the safety and health of people and also all the environmental elements (Situ and Emmons 2000).

(3) Green Crime: This term was first introduced by Lynch (1990). Later a book was written by him with the cooperation of Nancy Frank about green crime and its relation to the politics and the economy (Frank and Lynch 1992). This study was expanded over time and other criminologists and international institutions conducted researches on it. In the criminology literature, there is no single definition of green crime. But it can be said that green crime includes an act or omission that is both legal and illegal. For example, cutting some trees in an area is not a crime, but its continuation in the future may not be beneficial to the nature and the people in that area (White 2007). Thus, they can be considered legal actions, but at the same time, they are not considered as environmental crimes. In green criminology, crimes are seen from an environmental perspective. These crimes can be against human and a variety of species.

Perhaps the best idea to reach criminalization indices and to define green crime is to classify these crimes and to address each of them individually.

Generally green crime is conceivable in two ways:

(a) Crime that harms the environment directly; (b) Crime that causes environmental damage and disasters indirectly such as toxic waste disposal in the ground.

To better evaluate green crimes, it should be noted that, for example, who are the victims of these crimes, humans or non-humans, and the extent of damage inflicted on the regional or international level (White 2007). But there is a problem in this regard: Although the world media have tried to make people aware of the damage, those who damage the environment try to hide their unlawful acts with the help of politicians and this makes it difficult for criminologists to conduct researches and investigations (Lynch and Stretesky 2001).

(4) Many doctrines have also defined the environmental crime as Ecocide. Ecocide as a legal doctrine includes activities which damage the ecosystem, earth and the human, and finally leads to inability in use and exploitation of the land. It should be noted that the purpose of usage and exploitation is not the mere material use, but the activities that lead to the loss of visual pleasure and jeopardize the interests of animals are considered Ecocide (Higgins 2012).

Although various definitions of environmental crime have been offered by various institutions and individuals and these definitions are close to each other in meaning, no single definition of environmental crime as an international crime has been provided up to now. The reason is that to arrive at a single definition, the scope of environmental crime must be defined. In the meantime, many governments and politicians who feel that their interests are at risk try to avoid this.

Many lawyers have suggested that environmental crime be considered as the fifth international crime, and the International Criminal Court of Justice also has jurisdiction over this crime, along with four other crimes which are genocide, crimes against humanity, war crimes and the crime of aggression (Higgins 2012). The reason for this suggestion is that when crimes and their effects extend beyond the borders of states, no state has sufficient and necessary resources and power to combat this type of crime. Thus, there is a need for an institution to punish the offenders of such crimes, and because environmental crimes are transboundary crimes, many jurists have proposed the International Criminal Court of Justice to have jurisdiction over these environmental crimes. Those jurists believe that genocide is a barbaric act that leads to the disappearance of a group of people; environmental crime also leads to environmental damage that may be the cause of loss and destruction of many people. For example, drinking water contaminated with chemicals can cause the death of many people or has irreversible impacts on future generations such as the emergence of genetic disorders. 
Generally, three categories are considered for international crimes. But we cannot precisely find characteristics of environmental crimes in these three categories.

The first category of international crime is the crime dealing with human and drug trafficking. These crimes are considered so-called organized crime (Palermo Convention 2000). In the case of environmental crime, CITES Convention (1973) can be somehow similar to organized crime. The problem is that sometimes wildlife trafficking occurs within the borders of a country, not outside of it (Megret 2011).

The second category is related to the crimes committed in wartime or in an adversarial relationship between two or more countries. For example, the crime of aggression has been one of the most basic and important crimes listed in the Nuremberg Court. The important point here is that it is true that at the ICC Statute the environmental crimes during wartime have been discussed, but the problem is that most of the loss and damage that are inflicted on the environment are in peacetime not in wartime (Wattad 2009).

The third category of international crime emphasizes crimes against people and mainly addresses human rights issues. In this type of crime, borders have no meaning and if this type of crime happens within the borders of a country, it is important enough to affect the whole world (Prosecutor v. Tadic, Case No. IT-94-1-AR72, 1995).

Many scientists believe that environmental crimes are considered as a part of human rights crimes, and it can be said that environmental law is the basis and foundation of human rights; but in contrast, another group of environmental lawyers believe that some environmental crimes do not occur directly, therefore their effects are not known immediately, and thus they cannot cause a sudden shock to the international community. Therefore, environmental crimes cannot be classified as an absolute part of the last category. In other words, the effects of damage to the environment become apparent gradually over many years. However, it should be noted that the basis and foundation of environmental crimes are like other international crimes and all of them are crimes against humanity.

In 1997, the Judge Weeramantry in the case of Gabcikovo-Nagymaros which was a conflict between Hungary and Slovakia in the International Court of Justice stated in his independent and separate opinion that:

The protection of the environment is likewise a vital part of contemporary human rights doctrine, for it is a sine qua non for numerous human rights such as the right to health and the right to life itself. It is scarcely necessary to elaborate on this, as damage to the environment can impair and undermine all the human rights spoken of in the Universal Declaration and other human rights instruments. While, therefore, all peoples have the right to initiate development projects and enjoy their benefits, there is likewise a duty to ensure that those projects do not significantly damage the environment (Weeramantry 1997).

Many environmental lawyers believe that environmental crime should have international dimensions so that it can be considered a crime at international level; the crimes that occur in a country must have an international impact. For example, although drying a lake occurs within the borders of a country, it may have international dimensions. One of its impacts is that there may be very rare and specific species living in that lake, and in fact these species belong to the whole world not to a specific country; or environmental scientists have stated that in case of a lake drying on one side of the planet it can contribute to the loss of other resources on the other side of the planet. Therefore, environmental crime has certain characteristics which distinguish it from other international crimes.

\section{Efficiency of international instruments in relation to environmental crime}

The point that can be found in international instruments in relation to environmental crime is the fact that the more we move from the past to the present, the more the attention has been given to the environment and its protection, and it has been regarded as an independent issue and out of the ownership of human beings. For example, the Statute of the Nuremberg Military Tribunal has not directly mentioned environmental crime, but in the sixth article of this Statute there are examples of war crimes and crimes against peace. For example, paragraph (b) of this article says violation of any international law and customs related to war, including murder, ill-treatment, deportation, slavery, hostage, plunder and destruction of public or private property are considered crimes (United Nations International Law Commission 1945).

The four 1949 Geneva Conventions have adopted the same policy and considered the environment as the people's property and its destruction as a crime. Years later, Article 55 of Protocol I additional to the Geneva Conventions relating to the Protection of Victims of International Armed Conflicts directly addressed environmental crime in wartime and emphasized that:

1. Care shall be taken in warfare to protect the natural environment against widespread, long-term and severe damage. This protection includes a prohibition of the use of methods or means of warfare which are intended or may be expected to cause such damage to 
the natural environment and thereby to prejudice the health or survival of the population.

2. Attacks against the natural environment by way of reprisals are prohibited (Protocol I Additional to the Geneva Conventions 1977).

Moreover, the ENMOD Convention (1977) has banned any use of environmental modification techniques which causes widespread, long-lasting or severe damages in armed conflicts.

In later years, other conventions, such as the Convention on International Trades in Endangered Species of Wild Fauna and Flora (CITES Convention 1973), the international convention for the Prevention of Pollution from Ships (MARPOL Convention 1973) or the Convention on the Prevention of Marine Pollution by Dumping Waste and Other Matters (1972) in London, requested member states to pass necessary rules and regulations in the scope of the treaty. For example, Article 8 of CITES Convention has required that states shall take appropriate measures to enforce regulations of this convention such as to penalize trade in, or possession of such specimens (CITES Convention 1973).

But the important point that should be noted is that none of these treaties have offered a definition for the environmental crime. Even some conventions such as the Treaty on the Prohibition of the Emplacement of Nuclear Weapons and Other Weapons of Mass Destruction on the Seabed and the Ocean Floor and in the Subsoil (Seabed Arms Control Treaty 1971) allow states to ignore their membership in the treaty and to leave it in case of a threat to their country's interests.

In addition to the abovementioned treaties, two other conventions that directly propose environmental crime for discussion are: (1) the Rome Statute (1998) and (2) the Convention on the Protection of Environment through Criminal Law (1998), adopted by the European Union. Both instruments have been approved in the same year. As previously mentioned, the Rome Statute has been followed by the establishment of the International Criminal Court (ICC) of Justice. Article 8 of the ICC Statute is related to war crimes. Paragraph (iv) of Part (b) Subsection (2) of this article concerns the environment, and it prohibits intentional attack to the environment which causes incidental loss of life or injury to civilians, damage to civilian objects, widespread, long-term and severe damage to the environment which would be clearly excessive in relation to the concrete and direct overall military advantage anticipated (Rome Statute 1998).

In fact, this paragraph is a repetition of Article 55 of the four-treaty Geneva Protocol of 1971 with the difference that this protocol does not mention any relationship between military attack and destruction of the environment, and
Article 8 of the Rome Statute had a rollback comparing to Article 55 of the four-treaty Geneva Protocol of 1971.

The only remaining convention concerning the protection of the environment through criminal law is the European Union Convention of 1998 (Convention on the Protection of Environment through Criminal Law 1998). This convention is the only convention that addresses environmental crime regardless of wartime. The main characteristic of this convention is its regionality. In other words, only the European states are members of this convention. This convention consists of a preamble and 21 articles. The preamble of the convention states that it is better to prevent environmental damage primarily through preventive measures, but then criminal law can play a key role in this regard in the protection of the environment. Article 2 of the said convention defines environmental crimes in five categories and wants the states to take necessary measures in their domestic law to ratify these crimes when they are committed intentionally:

(a) The discharge, emission or introduction of a quantity of substances or ionizing radiation into air, soil or water which: (i) causes death or serious injury to any person, or (ii) creates a significant risk of causing death or serious injury to any person;

(b) The unlawful discharge, emission or introduction of a quantity of substances or ionizing radiation into air, soil or water which causes or is likely to cause their lasting deterioration or death or serious injury to any person or substantial damage to protected monuments, other protected objects, property, animals or plants;

(c) The unlawful disposal, treatment, storage, transport, export or import of hazardous waste which causes or is likely to cause death or serious injury to any person or substantial damage to the quality of air, soil, water, animals or plants;

(d) The unlawful operation of a plant in which a dangerous activity is carried out and which causes or is likely to cause death or serious injury to any person or substantial damage to the quality of air, soil, water, animals or plants;

(e) The unlawful manufacture, treatment, storage, use, transport, export or import of nuclear materials or other hazardous radioactive substances which causes or is likely to cause death or serious injury to any person or substantial damage to the quality of air, soil, water, animals or plants,

when committed intentionally (Convention on the Protection of Environment through Criminal Law 1998).

Article 3 also requires the states to adopt necessary measures to ratify the crimes referred to in Article 2 which 
are committed out of negligence. Article 4 deals with other environmental crimes which are not listed in Article 2 and urges the states to take the necessary steps to ratify the following crimes which are committed intentionally or out of negligence.

These crimes include the followings:

(a) The unlawful discharge, emission or introduction of a quantity of substances or ionising radiation into air, soil or water;

(b) The unlawful causing of noise;

(c) The unlawful disposal, treatment, storage, transport, export or import of waste;

(d) The unlawful operation of a plant;

(e) The unlawful manufacture, treatment, use, transport, export or import of nuclear materials, other radioactive substances or hazardous chemicals;

(f) The unlawful causing of changes detrimental to natural components of a national park, nature reserve, water conservation area or other protected areas;

(g) The unlawful possession, taking, damaging, killing or trading of or in protected wild flora and fauna species (Convention on the Protection of Environment through Criminal Law 1998).

The European Union's Environmental Criminal Convention can be considered as the most binding international criminal instrument. However, this convention is not free of fault. Firstly it is a regional convention and is therefore only applicable to the European Union countries, and secondly the legislator has established crimes in general and referred details to the domestic law, or the Council of Europe in the majority of articles regarded a reservation right for countries to accept. However, this convention can be a guide and model for other international environmental criminal instruments in the future.

Perhaps soft law has been developed more in the attention to environmental crimes. For example, the Resolution on the Role of Criminal Law in the Protection of Nature and the Environment (UNGA Res. 45/121 1990), the Resolutions of Economic and Social Council of the United Nations in 1993, 1994 and 1996 concerning the role of criminal law in protecting the environment (E.S.C. Res. 1993, 1994, 1996), or other international conferences such as the International Conference on Environmental Crime: Current and Emerging Threats (2012), held by the United Nations Interregional Crime and Justice Research Institute (UNICRI) and the United Nations Environmental Programme (UNEP), or the International Environmental Compliance and Enforcement Conference (2013), held in Nairobi, Kenya, all have tried to encourage the world states to pass or amend new criminal laws at national level in order to protect the environment. They also want the states in each region to try and coordinate their national and regional regulations with each other and all states to cooperate in order to develop an international convention on the protection of the environment through criminal law. Furthermore, these congresses and conferences such as the International Conference on Environmental Crime: Current and Emerging Threats (2012) offered suggestions about research and information exchange between states to prevent environmental crime at national, regional and international levels, combating organized environmental crimes and offenses and how to identify them, establishment of organizations at national level and their link with Interpol, and about considering the role of international organizations such as the International Maritime Organization (IMO), Europol, Eurojust and Interpol in fighting against environmental crimes. But the reality is that these instruments currently have no required enforcement and they are merely recommendations that can be useful for the future. On the other hand, a major problem in the relationship between environmental crimes and international law is the fact that the rate of commitment of environmental crime is increasing day by day in the world, and consequently its negative effects are more irrecoverable. In spite of this, the treaties and other international instruments are very slow moving toward the environmental criminalization. What would be punishable today as a crime against the environment at international level is only seen in wartime and other environmental crimes are punishable only by the internal law of the states? Furthermore, Europe and the states of this continent are the only regions in the world which are the members of a criminal convention for the prevention of environmental damage. Therefore, the current international instruments have not responded to crimes committed, and as long as the compensation and the civil liability of offenders are under discussion, environmental damage will certainly not decrease; because the profit earned from such damage is much greater than compensation.

\section{Different kinds of international environmental crime and their instances}

Up to the present time, no single classification of environmental crimes at the international level that would be acceptable to the international community has been provided. But it appears that with the study and analysis of international instruments, environmental crimes can be divided into six categories: (1) wildlife crime, (2) illicit transfer of hazardous waste, (3) crimes relating to climate change, (4) crimes relating to the production of any type of pollution, (5) illegal, unregulated, and unreported fishing and (6) illegal logging and trade in timber. 
It should be noted that despite the classifications above, environmental crimes are always related to each other, they influence each other, and in some cases there is not a clear border between them. For example, air pollution may accelerate the climate change and global warming while crimes of different kinds of pollution are separated from crimes related to climate change or as another example climate change and global warming can have a direct impact on the disappearance of many species or change their migration routes.

\section{Wildlife crime}

Wildlife crime is a type of environmental crime. Transboundary character in the environment causes the animal species hitting political boundaries freely, and therefore boundaries do not have a place in relation to them. These species are in danger in different ways. Many of them have been extinct or endangered due to indiscriminate hunting, illegal trade and the loss of their habitat. Statistics show that hunting and trafficking of different species have increased significantly in recent years. For example, about 15,000 elephants were killed in 42 zones in 2012 and over $500 \mathrm{~kg}$ of elephant ivory trade has been reported in 2013 . This amount increased significantly compared with the previous years. Trade in rhino horn is also not in a better condition compared with elephant ivory. Almost $94 \%$ of rhinoceros poaching takes place in Zimbabwe and South Africa. Total rhino population on the planet in 2010 was reported to be about 28,000 . In 2007 , about 50 of them were hunted, and hunting of rhinos in 2013 reached up to a 1000. The tiger is another species that has been endangered in the past hundred years. The total number of tigers in the world in the early twentieth century has fallen from 100,000 to less than 3000-3900 in the twenty-first century. For example, only between 1990 and 1992, about 27 million export of tiger products in China has been reported (Nellemann et al. 2014).

In addition, many of these species and their products are exported to developed countries. For example, the USA is one of the largest markets in the purchase and sale of different wild species and their products, and each year hundreds of millions of dollars in this trade are earned just in this country. It should be noted that the revenue of the average annual world trade in wild species is six billion dollars (Blevins and Edwards 2009). This can be due to several factors including huge revenues from hunting and trafficking of these species. In 2014, crimes against wildlife not only put it at risk, but the effects of these crimes can go beyond environmental damage and weaken other things such as economic development, people's livelihood, rule of law, democracy and finally security, and apart from this, revenues from the illicit trade of various species types are spent for the activities of terrorist groups (Nellemann et al. 2014).

Another reason for the increase in crimes against species is lack of private complainant in these types of crimes within the states, and the nature of these crimes is in a way that they have public attributes. Furthermore, the inefficiency and lack of coordination among international conventions and agreements, states' neglect in planning, adoption of appropriate criminal law and also lack of cooperation between states to protect the species and their habitats could be other reasons for the increase in crimes against a variety of species (De Klemm 1994).

\section{Crimes related to the unlawful transport of waste}

Crimes related to unlawful waste transport and disposal have not decreased despite numerous treaties such as the Basel Convention (1989). Even the definition of hazardous waste has not been agreed on at international level by all states, especially developed countries up to now (Brack and Hayman 2002). In the meanwhile, huge disasters occurred like dumping of 4000 tons of waste by Khian Sea ship in Gonaives in 1988 near Haiti (Hall 2012) or discharge of toxic waste of a Dutch company in 2006 by a Panamanian ship in the port of Abidjan, capital of Cote d'Ivoire (Amnesty International and Greenpeace Netherlands 2012).

In fact, most of unlawfully dumped waste belonged to the developed countries which has been dumped off in poor countries. In the early 1990s, the cost of dumping one ton of hazardous waste materials in the member states of the Organisation for Economic Co-operation and Development (OECD) was estimated to be between 100 and 2000 dollars, while this value in the African countries had been estimated to be between 2 and 50 dollars. So the main reason for the dumping of waste in developing countries is the payment of minimum cost and the lack of awareness in these countries. This actually means that these countries ignore the effects of hazardous wastes on their people's health and environment and in exchange for a small amount of money absolve offenders of all responsibility.

The main reason for the increase in the transport and disposal of waste is the inefficiency of international documents. For example, lack of proper monitoring of waste transport, lack of effective sanctions in dealing with offenders, acceptance of bilateral agreements on export of hazardous waste and recycling them and exploitation of the poverty and the poor conditions of the underdeveloped nations by the developed countries are the reasons for the failure in stopping unlawful waste transport and dumping. Therefore, as long as they do not deal decisively with offenders no reduction in this type of crime can be expected. In this regard, perhaps one of the most appropriate strategies is the adoption of necessary and integrated 
law and regulations in the world level in connection with the unification of international rates for hazardous waste dumping. In other words, if all countries have the same rate for waste dumping, it can be said that waste transport will not benefit the producing countries.

\section{Crimes relating to climate change}

In recent decades, climate change has been one of the most important problems in the world and some people believe that climate change continues to be a significant challenge for humanity's future. Some scientists believe that climate change is occurring naturally, and in contrast, some others consider human activities as the main cause of these changes (White 2011).

According to the researches of the Environmental Protection Agency (EPA), the earth's temperature has increased up to $0.8{ }^{\circ} \mathrm{C}$ over the past century, more than half of this increase has occurred in the last 25 years, and activities like the use of fossil fuels, deforestation and different industrial pollution have intensified global warming. For example, an increase in emissions of carbon dioxide and methane is one of the major causes of global warming. Although these gases are essential for life on earth, too much emission of these gases leads to global warming. With regard to greenhouse gas emissions and their remaining in the atmosphere, it will be very difficult to combat global warming (National Geographic News 2007).

According to the report of the Intergovernmental Panel on Climate Change (IPCC) in 2007, the earth's sea level by the end of the current century will increase $18-58 \mathrm{~cm}$ due to global warming. The twentieth century was the warmest period in the last 400 years. On the other hand, the effects of global warming on countries such as Canada and Russia between 2000 and 2004 had twice the average effect than it had on the rest of the world, and it is anticipated that if the current trend continues until 2040, the Arctic region will be free of ice and snow. These cases have had very severe adverse effects including disappearance of glaciers, destruction of sea corals, forest fires, tropical storms, extinction of marine species and change in the routes of migratory birds, all of which are resulted from this problem (National Geographic News 2007).

The above examples are the direct effects of global warming on the environment. In addition, climate change could also cause social impacts. Some scientists believe that the earth's temperature rise could have a direct connection with crime. For example, in a study conducted in the USA it has been demonstrated that in the states with a warmer weather, crime rates are higher than the cold states and the rest of North America (Ranson 2014).

Another social impact of climate change is the problems related to environmental migration. There can be various reasons for this kind of migration. For example, drought and lack of water, damage to agriculture and consequently a reduction in food, poverty, uninhabitability of some areas, etc. could be the reasons for migration. One of the areas that in the recent years caused environmental migration has been the low-lying islands. Because sea level rises as a result of global warming, these islands are submerged. For instance, two islands governed by the Kiribati were submerged totally between 1998 and 1999. Carteret island inhabitants also evacuated the island in 2005 and moved to another island. This problem becomes complicated when the poor and underdeveloped countries are affected. Moreover, in some countries like Bangladesh with a population of more than 1000 people per square kilometers is one of the coastal countries which could be at risk (Mayer 2011).

In recent years, numerous conventions like the United Nations Framework Convention on Climate Change (UNFCCC) (1992) and the Kyoto Protocol (1997) have been ratified to achieve stabilization of greenhouse gas concentrations and the common but differentiated responsibility of states. But these instruments and other summits of the United Nations in this regard have not been successful for different reasons. One of the most important reasons is the withdrawal of the USA, as one of the largest producers of greenhouse gases, from the Kyoto Protocol in March 2001 (Andrews 2014) and lack of necessary and sufficient enforcement to deal with offenders. In fact, the fines are much less than the state's revenue from activities that can speed up the process of climate change.

\section{Crimes relating to the production of any type of pollution}

Regarding the crimes relating to the production of any type of pollution, it should be pointed out that in the last 100 years, with the increase in population, communities' development and lack of attention to the environment, environmental pollution has reached a critical boundary, so that from the 1970s onwards the international community has always been thinking of seriously addressing different types of environmental pollution. Water pollution, soil pollution, air pollution and noise pollution are considered as the most important pollution of today. Although light pollution and visual pollution have been recently paid attention to, problems related to water pollution, soil pollution and air pollution are so big that states have given attention to these type of pollution as well. There are numerous sources of pollution. Waste pollution, oil pollution, pollution from nuclear and radioactive materials and pollution caused by emissions from fossil fuels are the most important sources of pollution. In retrospect, we can see that significant environmental events and disasters have 
occurred in each case. For example, oil pollution occurred by the Iraqi government during the first Persian Gulf War in 1991 totalled 240 million gallons of crude oil, all of which have been poured into the Persian Gulf (Epstein et al. 2003), and the oil pollution in 2010 resulting from the explosion of an offshore platform oil well in the Gulf of Mexico created spill and release of more than 200 million gallons of crude oil into the sea (Jayalakshmi 2015).

Pollution due to nuclear and radioactive activities is another important reason for pollution. For example, the lack of states' attention to the management of nuclear power plants can cause disasters like the Chernobyl disaster. The states' nuclear tests can also have irreversible effects on the environment and human health. New Zealand and Australian governments' complaint against the French government to the International Court of Justice (ICJ) in 1974 and 1995 on its nuclear tests in the South Pacific due to severe environmental damage is an example of the problems caused by nuclear testing of governments (ICJ Reports 1974a, b, 1995). The international community has always been wary of dealing with the issue of nuclear testing and ICJ advisory opinion in 1996 about the threat to use or use of nuclear weapons confirms this (ICJ Reports 1996).

\section{Illegal, unregulated and unreported fishing}

The situation of crimes related to fishery is not better than other crimes. These crimes are also known as illegal, unreported and unregulated (IUU).

The exact number of IUU fishery is not available, but it is estimated that a remarkable percentage of the world's fisheries are either illegal, or have not been reported or no special law has been applicable for them. For example, one of the species that have declined due to overfishing is cod and its main habitat is near the coast of North Atlantic. One important characteristic of this species is its long-lived and slow-growing feature. In other words, it takes a long time for this fish to reproduce and to restore itself to its original population. In the past few years due to overfishing of this kind of fish, cod is now facing a dramatic population decline (Brack and Hayman 2002). Another species that is in danger because of overfishing is the Caspian Sea sturgeon. What made this type of fish popular is its excellent caviar. About $90 \%$ of the world sturgeon is in the Caspian Sea. According to the report of the Caspian Fisheries Research Center in 2004, the number of fishes in this sea was about five million beluga, seven million stellate sturgeon and 36 million sturgeon, while according to the report of the Office of the Prosecutor General of Kazakhstan about $98 \%$ of fish stocks in the Ural-Caspian region were destroyed between 2002 and 2012 and the Russian government alone netted 16 tons of sturgeon in 2012 (Nellemann et al. 2014).

\section{Illegal logging and trade in timber}

Crimes related to illegal logging and trade in timber are one of the most important crimes at the international level. Some experts have estimated that the business worth of the illegal trade in timber is more than one-tenth of global business worth of other businesses and is accountable for more than 150 billion dollars in a year (Brack and Hayman 2002a). Illegal logging and timber trade occur when it is against national or international law; logging in a protected area is an example.

Statistics show that between 20 and $30 \%$ of timber production in Russia and, particularly, between 40 and $50 \%$ of logging in Siberia are illegal. Most of the timber trade is made in the northern hemisphere and in the developed and industrial countries. OECD members account for almost $90 \%$ of total timber imports (Brack et al. 2002). Weak and corrupt governments as well as earning huge profits are among important reasons for illegal logging (International Environmental Compliance and Enforcement Conference 2013).

Today, illegal logging and trade in timber can be indeed regarded as organized crimes done by mafia gangs. Logging can have very harmful effects on the environment and on humans. Climate change and increased carbon dioxide in the earth can be one of the negative effects of uncontrolled and illegal logging. Furthermore, many of these trees are rare species, and logging them can be unrecoverable. Logging in one area can cause the destruction of ecosystems, and consequently many animal species become either extinct or forced to migrate which can destroy the order of nature and ecosystems all over the world.

Apart from these, logging can have terrible effects on people's lives. Although in the short term local people who usually do not have a good financial situation are a help to cut down these trees and are happy to earn money, in the long term the deforestation will have adverse effects such as forcing the people of that region to migrate. In recent years, the international community has paid more attention to the issue of deforestation. For example, the G8 group has made efforts in recent years to investigate and discover the causes of increase in illegal logging and trade in timber and to combat it.

The European Union also made efforts to prevent illegal logging and its trade. Furthermore, CITES convention (1973) has asked the states to prevent illegal trade of tree species which are mentioned in the appendices and to enact law and regulations in their domestic law in this regard. There have also been other international institutions and organizations in operation for the prevention of illegal logging and trade in timber, but up to now no binding treaty on illegal logging and trade in timber has been approved. Generally, the point associated with the 
environmental crimes which can be stated with certainty is that governments and international organizations have failed up to now to prevent or reduce commitment of these crimes. In other words, domestic, international law and international efforts to develop international criminal law on environmental crime have failed. Now the question is: Given that all are aware of the environmental damage and its effects on humans and the environment, what are the challenges in the codification of indices of environmental criminalization as the fifth international crime?

\section{Challenges of environmental criminalization}

Many challenges exist in criminalization in every field and context, but concerning environmental crime, challenges of criminalization are more than in other fields. The main reason is that although states are trying to assert their sovereignty and the states' territory shows this fact, in reality the environment has no boundaries; for example, environmental pollution spreads to other parts of the earth through air or water, and other environmental damage such as indiscriminate logging can jeopardize the future of the planet. Therefore, the environment is dependent on the whole of humanity including future generations, and this characteristic of the environment makes international environmental criminalization difficult. The following part attempts to identify and investigate the challenges of environmental criminalization.

\section{Scope of environmental crime}

In the definition of environmental crime, the scope of crime is not revealed. Environmental damage at the international instruments is damage which is widespread, long term and severe. The question is: What do these concepts mean?

The widespread damage means large-scale damage which is irreversible. In other words, the extent of direct environmental degradation is immense; for example, large-scale deforestation is a typical of widespread damage. It should be noted that depending on each case of damage, the definition of widespread is different. For instance, in the example of deforestation, cutting down 20-30 trees is not considered a widespread damage, but in the case of a rare and endangered species of which there exist only 50, cutting 30 of them is an example of widespread damage. Therefore, each case must be carefully evaluated.

The long-term destruction is effects which appear after the destruction and are irreversible, i.e., nature has no self-purification for it. For example, in oil pollution in the ocean when the contamination is limited, after a while it can be seen that no pollution is in that area and because of the ocean's self-purification, the pollution is gone after a while. But in many cases, nature has no ability to deal with the destruction and pollution and to restore it to its original condition. In the recent example if oil pollution is in large scale, not only the ocean's water cannot deal with it, but the effects of this pollution are also long term and will be transferable to other parts of the world. As other examples, it can be cited of environmental disasters that have occurred throughout history, such as the explosion of the Chernobyl power plant, Bhopal disaster or Minamata disaster (Andrews 2014). In all these cases, the impact of environmental damage has continued up to now and will definitely continue in the future.

The severe damage, as the name suggests, means significant and irreversible effects which are caused by environmental damage. In some cases, the severity of the disaster is to the extent which affects the international community. For example, the effects of the Chernobyl power plant disaster have been so severe that many people who were in the explosion have had many problems and these problems have also been transferred to the next generations. What the world's environmental lawyers have unanimously expressed is that in case of environmental criminalization at the international level, those kinds of actions against the environment are considered crimes which inflict widespread, long-term and severe damage to the environment. But the point is the scope of these three indices. Some lawyers believe that with the establishment of the International Environmental Criminal Court of Justice, the scope of each of these indices must be left to the interpretation of the court. But the problem is that much of environmental damage is not widespread or indirectly done, but its implications are very widespread and harmful.

In fact, the boundary between minor damage to the environment and environmental crime is very difficult; there may be some seemingly small damage which will have a widespread and irrecoverable scope, and if we have a broad interpretation of environmental criminalization and broaden its scope, this problem may arise that sometimes reparable and minor damage to the environment is considered as crimes. Another point is that many lawyers believe that environmental crimes must cause international damage and their impacts are not limited to just one country. But the question arising here is: What is the meaning of the international impact? Does this mean that the impact of environmental damage must be seen directly at the international level? For example, many countries were affected by acid rain in the Chernobyl power plant disaster. This is an example of environmental damage 
which is directly understood, and its impact can be seen well beyond the borders of a country.

But the problem is that environmental damage is caused within a state's territory and is seemingly in the scope of sovereignty of the state where the crime has taken place on its territory, is such a crime a crime against the environment? For example, the elimination of wetlands by states to build a civil project is an internal issue and is just related to the state or states where the wetlands are located. It seems that the answer is negative in explaining that any damage to the environment which either directly or indirectly affects the international community and future generations shall be considered an environmental crime.

\section{Sovereignty of states}

Sovereignty can be defined as the supreme authority of a state in making decisions and implementing them. This principle was first expressed by French man Jean Bodin as the absolute sovereignty (Andrews 2011). In classic international law, the concept of state international sovereignty, independence and equality with other states and the criterion of state recognition from civil society is the state absolute sovereignty. This means that the state's power is the supreme power, unlimited and non-compliance; from this perspective, sovereignty includes both internal and external aspects:

Internal aspect of sovereignty means that the state can do regulation and management of the country without foreign intervention.

In the external aspect, a state is sovereign when it has independence and freedom in its foreign relations and does not follow others.

With the development of international law, the states' sovereignty decreased, the states accepted some restrictions on their sovereignty in favor of international order, and from the twentieth century the international community began to respect the principle of national sovereignty, codified and developed a wide range of international human rights law, international environmental law and other rules that would restrict state authority.

On the other hand, the decrease in the role of states' sovereignty in international law in recent decades has caused deep concern for them, while this is despite the fact that these are states which are the main actors in the development of international law. Environmental law also constitutes a part of international law. In fact, states have a deep fear of the decrease in their political power in the international arena, and especially on environmental issues, it is somewhat more complex, because they should not only take care of their own actions in relation to the environment under their sovereignty, but also take precautions to prevent actions that may cause environmental damage and adverse effects to other countries. Therefore, their sovereignty and freedom become more limited in this regard; furthermore, there are nowadays topics about the environment such as common heritage of mankind and rights of future generations, and in order to achieve these goals, there is a need for the decrease in the states' sovereignty and their increased responsibility to the international community (Van der vyer 2009).

Impact of international law on states' sovereignty is divided into three categories:

(a) The first category is a set of rules that relate to areas of the world which are not governed by any state and belong to all humanity. These rules are known as the common heritage of mankind such as the rules of the atmosphere, the oceans, the space, the ozone layer, and so on.

(b) The second category is a set of rules that relate to the relations between the states. In other words, these rules include the states' actions against the environment and their impacts on other states. Article 30 of the Charter of Economic Rights and Duties of States in this regard states that:

The protection, preservation and enhancement of the environment for the present and future generations is the responsibility of all States. All States shall endeavor to establish their own environment and development policies in conformity with such responsibility. The environmental policies of all States should enhance and not adversely affect the present and future development potential of developing countries. All States have the responsibility to ensure that activities within their jurisdiction or control do not cause damage to the environment of other States or of areas beyond the limits of national jurisdiction. All States should cooperate in evolving international norms and regulations in the field of the environment (UNGA Res. 29/3281 1974).

(c) The third category contains no international law, and this is when the states' actions against the environment in their own country do not have a direct impact on other states and the international community, but in the long term their impacts will be visible to other countries (Van der vyer 2009).

Some international instruments have attempted to decrease the sovereignty of states, but states always have some kind of dependence on their sovereignty, territories and the exploitation of their resources and always like to manage their resources traditionally and with absolute sovereignty. In the international conventions, states which cause damage to other states are responsible and liable to compensation. None of these conventions considered criminal liability for statesmen except in wartime. So it is 
extremely difficult to punish a state for its activities which will have effects on other regions in the future. However, these activities can be detrimental to the general order of the world, and according to Erga Omnes rights, the international community can react to it. But in fact no state has been punished for these acts up to the present time.

Judicial precedent about sovereignty principle also approves this. For example, in the Lotus case of 1927, the Permanent Court of International Justice (PCIJ) considers sovereignty principle more important than state flag principle (PCIJ Series 1927). In the Trail Smelter case, the arbitration states that no state has the right to use or permit the use of its territory in such a manner as to cause injury in or to the territory of another or the properties or persons (Trail Smelter 1941). In the Corfu Channel case, International Court of Justice (ICJ) states that it is the duty of each state not to consciously allow its territory to be used for activities that cause damage to other countries (ICJ Report 1949). In the Barcelona Traction case for the first time, Erga Omnes right is considered in a judicial resolution. In this resolution, it is acknowledged that there are commitments which the states are required to observe against the entire international community (ICJ Report, 1970). Finally, in the Gabcikovo-Nagymaros case the court emphasizes the logical and rational use of land and resources (ICJ Report 1997).

Therefore, as it can be seen, although the sovereignty principle has faded over time, criminal law and punishment are still in their infancy. The international community and international organizations attempt to develop them; however, states show resistance due to their sovereignty.

\section{Mens rea in environmental crime}

The principle is that a crime occurs when an act or omission which is prohibited by the law is associated with the mens rea. Whereas mens rea is a decision and ill will which happens inside and in the mind of the offender, it has many complexities. Now the question is: What are the characteristics of mens rea in the environmental crime?

Generally the principle and rule in international law say that the offender or offenders must be aware of their actions and deeds; in other words, there must be ill will in the commitment of a crime.

ICC Statute considers environmental crimes during wartime attributable only when they are committed with intention. Generally, in the rules relating to armed conflicts, intention or awareness of environmental degradation is a condition for the commitment of environmental crime, and offenses that occur due to negligence or imprudence are not considered as crime (Elwa Badar 2013). In fact, according to the existing legislation in relation to environmental crimes during wartime, environmental crime occurs when there exists ill will. According to civil law, when someone causes damage they must compensate it. This compensation can be in different ways including reinstatement of the environment and fine. Several international instruments, such as some treaties concerning the protection of the environment and the responsibility of the states, have been approved in this regard in different areas of the environment. Therefore, according to international instruments, international environmental crimes in peacetime are not considered crime. The question is: What would be the position of ill will in the acceptance of environmental crime as an international crime? Because most of environmental crimes occur collectively and it is improbable that severe environmental damage and destruction be committed individually. In other words, the extent of the scope of international environmental crime seems to be in such a degree which requires participation of many people in the commitment of the crime. Therefore, it seems that in most of the international environmental crime there is a plurality of criminal behavior, this criminal behavior can be act or omission, and establishment of causality relationship in collective crimes with different ill will can be very difficult. In other words, the dispersion of criminal will leads to the plurality of criminal behavior, the intention of the offenders is not clear, each with a specific intent to commit a crime, and in many cases they have not a common ill will and this dispersion of criminal will changes the nature of the crime.

Furthermore, much of the environmental damage today lacks mental element and ill will. Now the question is: Whether it can be considered as environmental crime? For example, are pollution and damage caused by the imprudence in dangerous activities such as nuclear power plants, oil platforms and factories manufacturing toxic chemical materials considered crime? Because the reality is that many environmental problems are created without ill will. The rule about the four international crimes states that having ill will and intent is prerequisites to establishment of these crimes. But one of the challenges of environmental criminalization is that if these crimes are only punishable when they are committed with ill will, many environmental disasters remain unpunished in the name of imprudence and negligence and acceptance of criminal responsibility based on ill will may be a way for more destruction of the environment. In this regard, the benefit that the offenders gain from environmental degradation is so high that they can hire the best and most experienced lawyers in defending themselves.

Regarding the aforementioned, a solution is that the international community formulates a general principle in relation to the environmental crime, puts the principle on criminal responsibility based on ill will, makes dangerous occupations and activities exception and considers any 
negligence and imprudence in these types of activities as ill will. To achieve this, there will be required an international will by the states, which in turn is a major challenge.

\section{Punishment of environmental crime}

Given the acceptance of environmental crimes and finding the offenders, the question is: What kind of punishment is appropriate for environmental crimes? What can be said for sure is that like other international crimes only a competent court can deal with these cases. This requires investigation and arrest of the offenders of environmental degradation. It is quite clear that, like other international crimes, prosecution of the offenders is not an easy task. Therefore, the question is: In the case of arrest and prosecution of the offenders by the international community in a competent court, what kind of punishment can be imposed on them?

Generally, environmental crimes can be attributed to two groups of people:

(1) Natural entities;

(2) Legal entities and on a wider scale the government;

The general principle about punishment is that no legal entity can be punished. For example, a company cannot be sentenced to prison apart from its people. Therefore, another solution should be found.

In the ICC Statute, leaders and people who have committed the crimes listed in this statute shall be prosecuted by this court. But the problem is more complicated in the case of environmental crimes, because many environmental crimes are not committed by an individual's order and a set of policies and decisions made by individuals over time leads to the commitment of such crimes. In this case, what should be done indeed?

Perhaps the best punishment for these types of cases will be by imposing penalties and sanctions. For example, when a state or an entity within a state commits environmental degradation, imposing different types of sanctions on that state or entity as well as their dependents may be an appropriate solution, sanctions such as suspension of their membership in the international organizations, different kinds of economic sanctions imposed by other countries, closing and freezing their bank accounts or imposing penalties on them until they give up environmental degradation and trying to compensate for the losses. In fact, sanctions and penalties are appropriate solutions when we cannot particularly deem individual guilt of a crime and a group in the form of an institution or a state committing environmental degradation.

Such crimes are usually repeated over and over, and the reason is exploitation and gaining huge profits. For example, lack of states' attention to emissions of greenhouse gases and their quota according to the relevant conventions can be an example of commitment of environmental crime by them. In this case, other states can impose sanctions or financial penalties on the offending states. Furthermore, crimes committed by individuals or by their order must be dealt with by a competent court, and their punishment shall be certainly like other international crimes and includes imprisonment, penalties or dismissal from the service.

Therefore, formulation of environmental crimes and punishments involves complexities, and it certainly requires time and judicial procedures to be solved.

\section{Common heritage of mankind and the rights of future generations}

The concept of common heritage of mankind has been one of the most extraordinary developments in intellectual history in recent decades. Theoretically, prevention of environmental crime is successful when the benefits of humans, animals and generally the environment are considered, there actually exists a balance between humans and the environment, the enacted law includes human rights and their duties toward the environment, the current and future generations, and before any activity they take into account probable environmental damage.

Generally, three types of common heritage of mankind are accepted: The first type consists of items which are located within the borders of a country, but their absence can affect humanity, like the Amazon Rainforest which is like the lungs of the earth, and destroying it can have devastating effects such as change in the temperature of the earth. The second type of common heritage of mankind is the regions of the world which are not owned by any state such as Antarctica or open seas and their depths. The third type of this heritage is resources which have no boundaries such as water and air, and they do not fit into the countries and their boundaries. But the question is: Whether the common heritage of mankind cannot include a lake or a wetland in a particular country? Whether the disappearance of lakes, wetlands and ecosystems cannot affect other countries as well as future generations?

That is why different definitions of the concept of common heritage of mankind are presented. For example, according to Richardson (1990) the concept of common heritage of mankind will be extended to the whole world with an ecological system and it is specified by the states' commitment to the protection of wild species and ecosystems for the benefit of the entire international community. In another definition, the concept of common heritage of mankind is defined as a concept that shows total commitment to the preservation and protection of the environment and natural resources, whether it is defined in the national territory or beyond (Koester 1990). Therefore, whether environmental resources in the world belong to all 
humanity or they are under sovereignty of particular states, it makes environmental criminalization complicated. But what makes the problem more complicated is the rights of future generations. The rights of future generations have always been stressed in the international instruments. But the details are not clear. What kind are these rights or can the people who do not respect these rights be considered offenders? In recent years, numerous treaties have been ratified for the protection of the environment, space, polar and seas, but none of them state that environmental degradation is a crime. Moreover, the question still remains to be answered: Are other environmental sources such as lakes, forests, variety of species and wetlands, which are under sovereignty of particular states, considered common heritage of mankind? What is the position of rights of future generations in relation to the environment and is the violation of these rights considered an environmental crime?

\section{Conclusion}

It took a long time for the international community to find out the fact that environmental protection and human life are closely related. Therefore, some efforts have been made in the recent decades at the international level to prevent environmental damage in the form of hard and soft laws. But generally, these instruments have not been able to stop the growing trend of environmental damage. One of its main reasons is that these instruments have had no effective enforcement and have not considered environmental damage in peacetime a crime, and they have referred the codification of environmental criminal law to the states' domestic law and have considered environmental damage during wartime as a crime under certain conditions.

This study attempted to investigate the inefficiency of existing international instruments, because one of the important characteristics of the environment is its transboundary characteristic. Therefore, environmental criminalization is not enough merely in states' domestic law; furthermore, international environmental criminalization needs definition of environmental crime and its different kinds. This study classified and investigated environmental crimes in six areas: wildlife crime; crimes related to the unlawful transport of waste; crimes relating to climate change; crimes relating to the production of any type of pollution; illegal, unregulated and unreported fishing and illegal logging and trade in timber. Then this question was answered: Why the international community while aware of the importance of international environmental criminalization has not attempted to do so and what challenges have existed in this area? Obviously, the first step in solving a problem is its identification. Hence, this study attempted to identify and investigate the main challenges and obstacles in codification of environmental criminalization at the international level. Hence, sovereignty of sates, environmental crime and clarification of its boundaries with the environmental damage, mens rea in environmental crime, punishments in environmental crime and common heritage of mankind and the rights of future generations were introduced and suggested as the main existing challenges, and their impact on environmental crime and its acceptance as the fifth international crime were investigated. Perhaps identification and investigation of the said challenges will be the solution for the convergence of the political will of states to achieve a single international instrument on the criminalization of environmental damage.

\section{References}

Amnesty International and Greenpeace Netherlands (2012) The toxic truth. Amnesty International Publications, London

Andrews E (2011) Jean Bodin on Sovereignty. Repub Lett J Study Knowl Polit Art Stanf Univ 2(2):75-84

Andrews GC (2014) Canadian professional engineering and geoscience- practice and ethics. Nelson Education LTD., 5th edition

Basel Convention (1989) Convention on the control of transboundary movements of hazardous wastes and their disposal. Adopted 22 March 1989, Basel

Blevins K, Edwards T (2009) Wildlife crime. In: Miller J (ed), 21st Century criminology: a reference handbook. SAGE Publications, Inc., Thousand Oaks, pp 557-564. doi:10.4135/9781412971997. n65

Brack D, Hayman G (2002) Workshop report: international environmental crime: the nature and control of environmental black markets. Sustainable Development Programme, Royal Institute of International Affairs, UK. http://ec.europa.eu/environment/ archives/docum/pdf/02544_environmental_crime_workshop.pdf. Accessed 15 Nov 2014

Brack D, Gray K, Hayman G (2002) Report: controlling the international trade in illegally logged timber and wood products. Sustainable Development Programme, Royal Institute of International Affairs, UK. http://www.unece.lsu.edu/responsible trade/documents/2003-2006/rt03_022.pdf. Accessed 27 Jan 2015

CITES Convention (1973) Convention on international trades in endangered species of wild fauna and flora (CITES). Opened for signature March 3, Washington

Clifford M (1998) Environmental crime: enforcement policy and social responsibility. Jones and Bartlett learning

Convention on the Prevention of Marine Pollution by Dumping Waste and Other Matters (1972) Opened for signature 29 Dec 1972, London

Convention on the Protection of Environment through Criminal Law (1998) Opened for signature 4 Nov 1998, Strasburg

De Klemm C (1994) The problem of migratory species in international law. In: Bergesen HO, Parmann G (eds) Green globe year book of international co-operation on environment and development. Oxford University Press, Oxford, pp 66-77

Earth Summit (2002) World summit on sustainable development (WSSD), Johannesburg. www.earthsummit2002.org/. Accessed 16 Dec 2014 
Elwa Badar M (2013) The concept of mens Rea in international criminal law. Hart Publishing, London

ENMOD Convention (1977) Convention on the prohibition of military or any other hostile use of environmental modification technologies (ENMOD). Adopted 18 May Geneva

Epstein L, Jaco CD, Iwersen-Neimann JC (2003) The complete idiot's guide to the politics of oil. Penguin

E.S.C. Res. 1993/28. The role of criminal law in the protection of the environment 1993

E.S.C. Res. 1994/15. The role of criminal law in the protection of the environment, 1994

E.S.C. Res. 1996/10. The role of criminal law in the protection of the environment, 1996

UNGA Res. 29/3281 (1974) Charter of economic rights and duties of states. UN Doc A/RES/29/3281, 12 Dec 1974

UNGA Res. 45/121 (1990) Resolution on the role of criminal law in the protection of nature and the environment. UN Doc A/RES/ 45/121, 14 Dec 1990

Frank N, Lynch MJ (1992) Corporate crime, corporate violence. Harrow and Heston, Albany, NY

Gibbs C, Gore ML, Mcgarrell EF, Rivers L (2010) Introducing conservation criminology towards interdisciplinary scholarship on environmental crimes and risks. Br J Criminol 50(1):124-144

Hall MR (2012) Historical dictionary of Haiti. Scarecrow Press, Lanham

Higgins P (2012) Earth in our business: changing the rules of the game. Shepheard-Walwyn (Publishers) LTD, London

International Conference on Environmental Crime: Current and Emerging Threats (2012) Rome, United Nations Interregional Crime and Justice Research Institute (UNICRI). http://www. unicri.it/topics/environmental/conference/. Accessed 14 Dec 2014

International Environmental Compliance and Enforcement Conference (2013) Nairobi, Kenya, United Nations Environment Programme (UNEP) website. http://www.unep.org/environ mentalgovernance/Events/InternationalEnvironmentalComplian ceEnforcement/tabid/130472/Default.aspx. Accessed 17 Dec 2014

Jayalakshmi K (2015) BP oil spill: study traces almost 10 million gallons to gulf sea floor. International business times website. http://www.ibtimes.co.uk/bp-oil-spill-study-traces-almost-10million-gallons-gulf-sea-floor-1485834. Accessed 8 Feb 2015

Koester V (1990) From Stockhom to Brundtland. Environ Policy Law J 20(1/2):14-19

Kyoto Protocol (1997) Kyoto protocol to the United Nations framework convention on climate change. Adopted 10 Dec 1997, Kyoto

Lynch MJ (1990) The greening of criminology: a perspective on the 1990s. Critical Criminol 2(3):3-4, 11-12

Lynch MJ, Stretesky P (2001) Toxic crimes: examining corporate victimization of the general public employing medical and epidemiological evidence. Crit Criminol 10(3):153-172

MARPOL Convention (1973) International convention for the prevention of pollution from ships, international maritime organization (IMO). Adopted 2 Nov 1973

Mayer, B. (2011) The international legal challenges of climateinduced migration: proposal for an international legal framework. Colo J Int Environ Law Policy 22(3):357-416

Mclaughlin R (2000) Improving compliance: making non-state international actors responsible for environmental crimes. Colo J Int Environ Law Policy 11(2):377-410

Megret F (2011) The problem of an international criminal law of the environment. Columbia J Environ Law 36(2):195-257

National Geographic News (2007) Global warming fast facts. National Geographic News Website. http://news.nationalgeographic.com/ news/2004/12/1206_041206_global_warming.html. Accessed 14 Nov 2014

Nellemann C, Henriksen R, Raxter P, Ash N, Mrema E (eds) (2014) The environmental crime crisis-threats to sustainable development from illegal exploitation and trade in wildlife and forest resources. A UNEP rapid response assessment. United Nations Environment Programme and GRID-Arendal, Nairobi and Arendal, www.grida.no. ISBN: 978-82-7701-132-5. Printed by Birkeland Trykkeri AS, Norway

Palermo Convention (2000) United Nations convention against translational organized crime and the protocols thereto. Adopted 15 Nov 2000, entered in force 29 Sept 2003

Protocol I Additional to the Geneva Conventions (1977) Protocol additional to the geneva conventions of 12 August 1949, and relating to the protection of victims of international armed conflicts, 8 June 1977. Art. 35(3). Adopted 8 June 1977, Geneva

Ranson M (2014) Crime, weather and climate change. J Environ Econ Manag 67(3):274-302

ICJ Reports (1949) Corfu channel case (United Kingdom of Great Britain and Northern Ireland vs. Albania), vol I-VI, pp 242-265

ICJ Reports (1970) Barcelona Traction, light and power company, limited, second phase, judgment, p 32, paras 33-4

ICJ Reports (1974a) Nuclear tests case (Australia v. France), p 253

ICJ Reports (1974b) Nuclear tests case (New Zealand v. France), p 457

ICJ Reports (1995) Nuclear tests case (New Zealand v. France), p 288

ICJ Reports (1996) Advisory opinion of legality of threat or use of nuclear weapons, p 226

ICJ Reports (1997) Gabcikovo-Nagimaros project (Hungary vs. Slovakia), p 3

Richardson BJ (1990) A study of Australian practice pursuant to the world heritage convention. Environ Policy Law J 20(4/ 5):143-154

Rio Conference (1992) The United Nations conference on environment and development. Rio de Janeiro, United Nations Environment Programme (UNEP) website. http://www.unep.org/ Documents.Multilingual/Default.asp?documentid=78\&articleid= 1163. Accessed 15 Dec 2014

Rio +20 Conference (2012) United Nations conference on sustainable development. Rio de Janeiro, United Nations Website. http://www.un.org/en/sustainablefuture/. Accessed 15 Dec 2014

Rome Statute (1998) Rome statute of the international criminal court. Adopted 17 July 1998, Rome

Seabed Arms Control Treaty (1971) Treaty on the prohibition of the emplacement of nuclear weapons and other weapons of mass destruction on the seabed and the ocean floor and in the subsoil. Adopted $11 \mathrm{Feb}$ 1971, entered in force 18 May 1972

PCIJ Series (1927) Series A. Lotus case (France vs. Turkey), No. 10, p 26

Situ Y, Emmons D (2000) Combating environmental crime: prosecution. Environmental crime: the criminal justice system's role in protecting the environment. SAGE Publications, Inc., Thousand Oaks, CA, pp 147-177. doi:http://dx.doi.org/10.4135/ 9781452232256.n8

Smith S (1995) Changing corporate environmental behavior: criminal prosecution as a tool of environmental policy, in Eckersley, markets, bureaucracy, and the environment: new directions in governance. MacMillan Press, New York

Stockholm Conference (1972) United Nations conference on the human environment. Stockholm, United Nations environment programme (UNEP) website. http://www.unep.org/Documents. Multilingual/Default.asp?documentid $=97 \&$ articleid $=1503$. Accessed 12 Dec 2014

Prosecutor v. Tadic, Case No. IT-94-1-AR72 (1995) Decision on the defense motion for interlocutory appeal on jurisdiction, pp 57-58. Int'l Crim. Trib. for the Former Yugoslavia 
Trail Smelter Arbitration (United States vs. Canada) (1941) Encyclopedia of international law, vol 2, pp 276-280

United Nations Framework Convention on Climate Change (UNFCCC) (1992) Adopted 9 May 1992, 1771 U.N.T.S. 107 (entered into force Mar 21, 1994), New York

United Nations International Law Commission (1945) The charter and judgment of the Nurnberg Tribunal-history and analysis, document no. A/CN.4/5

Van der Vyer JD (2009) The environment: state sovereignty, human rights and armed conflict. Emory Int Law Rev 83(1):85-112

Wattad MSA (2009) Rome statue and captain planer: what lies between crimes against humanity and natural environment, 19 Fordham environmental. Law Rev 19:265-285
Weeramantry (1997) Gabcikovo-Nagymaros Case (Hungary vs. Slovakia) Separate opinion. International court of justice (ICJ) website. Available at www.icj-cij.org/dochet/index.php/p1. Accessed 5 Jan 2015

White R (2007) Environmental harm, ecological justice and crime protection, the challenge to criminology. Conference: improving community safety, lessons from the country and the city, Queensland, Australia

White R (2011) Translational environmental crime, toward an ecoglobal criminology. Taylor and Francis Group, Routledge 